\title{
Career Patterns in Medicine
}

MARYLAND Y. PENNELL, M.Sc. Hyg.

G RADUATION from medical school marks the beginning of a physician's career. Acquisition of the M.D. degree is usually followed by a period of apprenticeship experience for the young doctor to further his medical knowledge while he makes his choice of specialty and type of practice. Hopefully he will become well trained to handle the complexities of private practice either as a general practitioner or a specialist. Or he may decide to avail himself of special opportunities in teaching, administration, research, public health, or industry.

Information on how the physician undertakes his career in medicine can be deduced from data on individual doctors of medicine recorded by the American Medical Association. One procedure is to follow a single graduating class over an interval of years. A second procedure is to take a single look at consecutive graduating classes, assuming that their orderly progression will establish the pattern of career choice. The second method is the one used in this presentation. Data as of mid-1962 for physicians graduated from U.S. medical schools in the classes of 1948 through 1961 are used. These provide information as to type of practice, specialization, and certification during the first 14 years after graduation.

\section{Type of Practice}

Training programs. Four academic years in a medical school lead to the granting of the M.D. degree. Only in a few schools has the time been shortened as a result of experiments in curriculums. The physician's postgraduate education begins with his internship year, usually in or near a good medical center. All but

Mrs. Pennell is chief, Health Manpower Statistics Branch, National Center for Health Statistics, Pub. lice Health Service. At the time she wrote this paper she was chief, Health Manpower Branch, Division of Public Health Methods. a few of the young doctors continue their professional life in a hospital setting the first year after graduation. In this learning experience in direct care of the sick under the guidance of the professional staff of the hospital, the intern takes on the responsibility of being his patient's physician.

The intern's educational experience may be in only one department of the hospital if he is serving a straight internship or in several departments if he has a rotating or mixed internship. The straight internships are usually in internal medicine, surgery, pediatrics, pathology, or obstetrics and gynecology. They account for almost one in five filled positions and become the first step toward specialization (1).

About two-thirds of the young physicians also spend their second year after graduation in residency training (table 1 ). If the first year has been spent in a rotating internship, this experience may continue for a second year.

That more than half of the graduating class continue their postgraduate education into the third and fourth years reflects their desire to become specialists. The young physician will need several years of residency training if he is to meet the standards for certification set by a national board in each specialty. These standards generally specify at least 2 years of residency or other formal training following an approved internship and may require as many as 5 years.

This postgraduate education may be taken in consecutive years or in interrupted periods. As a resident, the young physician acquires experience and knowledge in his specialized field. He may assume added responsibility for training interns and perhaps medical students, although his own learning receives top priority.

The average time spent in training programs (internships and residencies combined) is 4.0 years per physician, based on the data in table 1. About 2 percent of the physicians are still engaged full time in postgraduate education 
some 10 to 14 years after graduation from medical school (fig. 1).

Federal service. During the second year out of medical school, about one in five physicians is employed by the Federal Government, is on active duty as a commissioned medical officer (regular or reserve) of the United States Air Force, Army, Navy, or Public Health Service, or is a permanent full-time medical officer of the Veterans Administration. Physicians employed as civilians by these agencies or associated with other Federal agencies are included with non-Federal physicians by the American Medical Association. Interns and residents in Federal hospitals are likewise excluded from this ratio since they have been counted among those in training programs.

The proportion of recent graduates in Federal service, as defined in the preceding paragraph, stays in or near the 20 percent level from the second through the sixth year following graduation. The level gradually decreases to about 5 percent from the ninth year on. Thus about 1 in 20 of these graduates of U.S. medical schools becomes a career Federal medical officer.
Data for all graduates of U.S. and foreign medical schools in this country in 1962 indicate that 16,531 out of 257,035 physicians are in Federal service (excluding interns and residents). Thus 6.4 percent of all physicians are currently Federal medical officers.

The statistics in table 1 lead to the calculation that about half of these recent graduates have served their 2-year military obligation. Information from the Selective Service System and the Department of Defense bears out this deduction.

Private practice. As young physicians complete their internship and residency training, they usually enter Federal service or private practice. By the second year after graduation about one in nine has already started in private practice. By the seventh year the proportion has exceeded half; by the ninth year, three-fourths.

During the first 14 years out of medical school, the average doctor has been engaged in private practice for 6.9 years. This accounts for almost half of his entire time since graduation.

Data for all physicians in the United States

Table 1. Type of practice in 1962 of physicians graduated from U.S. medical schools in 1948-51

\begin{tabular}{|c|c|c|c|c|c|c|c|}
\hline \multirow{2}{*}{ Year graduated } & \multirow{2}{*}{$\begin{array}{c}\text { Total } \\
\text { number of } \\
\text { graduates }\end{array}$} & \multicolumn{5}{|c|}{ Percent of graduates in U.S. by type of practice } & \multirow{2}{*}{$\begin{array}{l}\text { Percent } \\
\text { not in } \\
\text { U.S. or } \\
\text { deceased }\end{array}$} \\
\hline & & $\underset{\text { programs }}{\text { Training }}$ & $\begin{array}{c}\text { Federal } \\
\text { service }^{2}\end{array}$ & $\begin{array}{l}\text { Private } \\
\text { practice }\end{array}$ & $\begin{array}{c}\text { Other } \\
\text { practice }^{3}\end{array}$ & Inactive & \\
\hline $\begin{array}{l}1961 \\
1960 \\
1959 \\
1958 \\
1957\end{array}$ & $\begin{array}{l}6,994 \\
7,081 \\
6,860 \\
6,861 \\
6,796\end{array}$ & $\begin{array}{l}\text { 98. } 9 \\
65.1 \\
57.8 \\
56.2 \\
42.8\end{array}$ & $\begin{array}{r}0.1 \\
20.0 \\
23.0 \\
18.1 \\
17.8\end{array}$ & $\begin{array}{r}0.2 \\
11.5 \\
15.4 \\
19.7 \\
31.1\end{array}$ & $\begin{array}{l}0.4 \\
\text { 1. } 9 \\
\text { 2. } 1 \\
\text { 3. } 4 \\
\text { 5. } 4\end{array}$ & $\begin{array}{r}0.1 \\
.4 \\
.4 \\
.5 \\
.5\end{array}$ & $\begin{array}{l}0.3 \\
1.1 \\
\text { 1. } 3 \\
2.1 \\
\text { 2. } 4\end{array}$ \\
\hline $\begin{array}{l}1956 \\
1955 \\
1954 \\
1953 \\
1952\end{array}$ & $\begin{array}{l}6,845 \\
6,977 \\
6,861 \\
6,668 \\
6,080\end{array}$ & \begin{tabular}{r|}
34.7 \\
22.0 \\
10.1 \\
5.2 \\
3.4
\end{tabular} & $\begin{array}{r}\text { 17. } 8 \\
\text { 13. } 1 \\
\text { 8. } 4 \\
\text { 5. } 1 \\
\text { 4. } 8\end{array}$ & $\begin{array}{l}\text { 38. } 1 \\
\text { 53. } 0 \\
67.8 \\
\text { 75. } 2 \\
\text { 78. } 0\end{array}$ & $\begin{array}{r}6.5 \\
9.4 \\
10.5 \\
11.1 \\
10.8\end{array}$ & $\begin{array}{l}.5 \\
.4 \\
.6 \\
.4 \\
.7\end{array}$ & $\begin{array}{l}\text { 2. } 4 \\
2.1 \\
\text { 2. } 6 \\
\text { 3. } 0 \\
\text { 2. } 3\end{array}$ \\
\hline 1951 & $\begin{array}{l}6,135 \\
5,553 \\
5,094 \\
5,543\end{array}$ & $\begin{array}{l}\text { 2. } 4 \\
\text { 2. } 1 \\
\text { 1. } 7 \\
\text { 1. } 7\end{array}$ & $\begin{array}{l}\text { 4. } 2 \\
\text { 4. } 4 \\
\text { 6. } 3 \\
\text { 5. } 5\end{array}$ & $\begin{array}{l}\text { 77. } 7 \\
78.2 \\
72.3 \\
75.9\end{array}$ & $\begin{array}{l}\text { 10. } 3 \\
11.5 \\
12.6 \\
11.0\end{array}$ & $\begin{array}{l}.8 \\
\text { 1. } 3 \\
\text { 1. } 2 \\
\text { 1. } 1\end{array}$ & $\begin{array}{l}\text { 4. } 6 \\
2.5 \\
\text { 5. } 9 \\
\text { 4. } 8\end{array}$ \\
\hline
\end{tabular}

1 Federal and non-Federal interns and residents.

2 Federal physicians in any form of practice other than training programs. Includes Federal physicians outside the United States.

3 Non-Federal physicians in hospital service, teaching, administration, research, and preventive medicine.

Sources: Total graduates is from Nunemaker, J. C., Thompson, W. V., and Tracy, R.: Graduate medical education in the United States. JAMA 186: 661 (table 7), Nov. 16, 1963. Type of practice is as shown on individual physician punchcards supplied by the American Medical Association to the Public Health Service as of mid1962. 
Figure 1. Career patterns in medicine

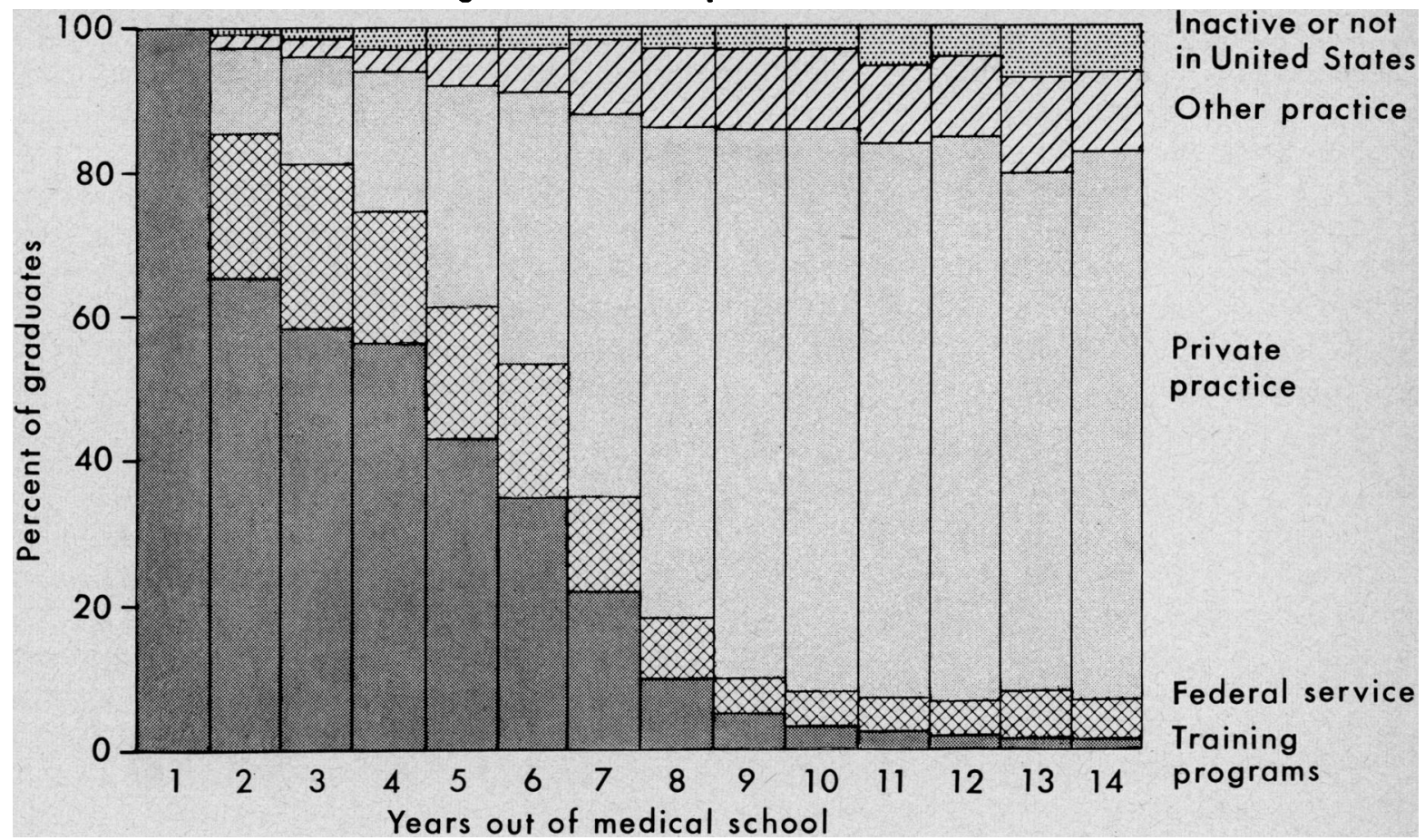

indicate that 66.2 percent were engaged in private practice in 1962 . These non-Federal physicians provide general or specialty service, their professional income derived from fees for service or salary. They may practice in a group, a partnership, or on an individual basis.

Other practice. Various other forms of practice engaged in full time by non-Federal physicians include service (other than training programs) in a hospital; on a medical school faculty ; in administrative, laboratory, or preventive medicine; and in research. These physicians are generally salaried rather than self-employed.

Not many of the young doctors, however, start out in such activities. In the second year after graduation, the proportion is less than 2 percent; by the fifth year, up to 5 percent; by the eighth year, 10 percent. The proportion stays at about 10 to 12 percent thereafter (table 1).

In 1962, 8.7 percent of all physicians in this country were engaged in non-Federal hospital service or other forms of practice. NonFederal hospital service accounted for 3.9 percent; other forms of practice, for 4.8 percent.

Inactive. Even in the first year out of medical school a few physicians do not practice med- icine in any form. The proportion who withdraw from active status remains at less than 1 percent, however, up to the 12 th year after graduation.

In 1962, 4.8 percent of all physicians in this country were reported by the American Medical Association as inactive. Those retired totaled 3.9 percent; those in other than medical practice, 0.9 percent.

Outside the United States. The two sets of American Medical Association records, on medical graduates and subsequent type of practice, when combined as in table 1 , would indicate that from 1 to 5 percent of the recent graduates of U.S. medical schools are not included in the physician supply of this country. These doctors may be deceased, or they may be non-Federal physicians located outside of the United States (which in our terminology includes Puerto Rico and other U.S. outlying areas). Very few are in the category of address temporarily unknown to the AMA.

\section{Specialization}

That nearly every doctor desires to be a spocialist is borne out by the 1962 data for the country as a whole, which shows that two of 
three active physicians specialize. Of the 257,035 total physicians, 171,118 are specialists, including those who are specializing while in training programs. There are 129,838 Federal and non-Federal physicians who limit their practice to a specialty-whether in private practice, hospital service other than interns and residents, or other forms of practice, according to data in table 6 of Health Manpower Source Book 14 (Q). An additional 12,899 physicians in private practice give special attention to a specialty. Of those spending full time in training programs, 28,381 indicate a specialty other than general practice.

Almost one in six interns specializes in his first year of postgraduate training. By the second year two-thirds have made a choice of specialty, the proportion gradually increasing to about three-fourths of these young physicians (table 2).

Surgery and related fields are the primary choice of the largest numbers who specialize. For example, of the 4,193 physicians graduated in 1948 who were specialists in 1962, 1,740 were in the surgical field. These included 592 in general surgery, 394 in obstetrics-gynecology,
207 in anesthesiology, 190 in ophthalmologyotolaryngology, 130 in orthopedic surgery, and fewer numbers in neurological surgery, plastic surgery, proctology, thoracic surgery, and urology.

Medical fields are the choice of the second largest numbers of specialists. Those graduated in 1948 included 1,483 such specialists962 in internal medicine with an additional 63 in its subspecialties of allergy, cardiovascular disease, gastroenterology, and pulmonary diseases; 390 in pediatrics; and 68 in dermatology.

The third choice for these young physicians is one of a combination of the remaining specialties, after excluding psychiatry and neurology. Those graduated in 1948 included 529 "other" specialists of whom 254 were radiologists, 139 were pathologists, 108 were in preventive medicine and its special fields of aviation medicine, occupational medicine, and public health; 17 were in physical medicine and rehabilitation; and 11 were in administrative medicine.

Lesser numbers chose psychiatry and neurology as their primary specialty. Among those graduated in 1948, 441 selected psychiatry or neurology.

Table 2. Specialization in 1962 of physicians graduated from U.S. medical schools in 1948-61

\begin{tabular}{|c|c|c|c|c|c|c|c|}
\hline \multirow{2}{*}{ Year graduated } & \multirow{2}{*}{$\begin{array}{l}\text { Number } \\
\text { active } \\
\text { in U.S. } \\
\text { in } 1962\end{array}$} & \multirow{2}{*}{$\begin{array}{l}\text { Number } \\
\text { special- } \\
\text { ized }{ }^{1}\end{array}$} & \multicolumn{5}{|c|}{$\begin{array}{c}\text { Percent of active physicians with designated } \\
\text { specialization }\end{array}$} \\
\hline & & & $\begin{array}{c}\text { Any } \\
\text { specialty }\end{array}$ & Medical ${ }^{2}$ & Surgical ${ }^{3}$ & $\begin{array}{c}\text { Psychiatry, } \\
\text { neurology }\end{array}$ & Other ${ }^{4}$ \\
\hline $\begin{array}{l}1961 \\
1960 \\
1959 \\
1958 \\
1957\end{array}$ & $\begin{array}{l}6,961 \\
6,975 \\
6,747 \\
6,681 \\
6,599\end{array}$ & $\begin{array}{l}1,218 \\
4,722 \\
4,674 \\
4,919 \\
5,002\end{array}$ & $\begin{array}{l}17.5 \\
67.7 \\
69.3 \\
73.6 \\
75.8\end{array}$ & $\begin{array}{l}11.6 \\
26.0 \\
23.7 \\
23.7 \\
25.1\end{array}$ & $\begin{array}{r}4.9 \\
26.8 \\
28.7 \\
32.9 \\
33.4\end{array}$ & $\begin{array}{l}0.1 \\
\text { 7. } 0 \\
\text { 8. } 1 \\
\text { 7. } 8 \\
\text { 7. } 6\end{array}$ & $\begin{array}{l}0.9 \\
7.9 \\
8.8 \\
9.2 \\
9.7\end{array}$ \\
\hline $\begin{array}{l}1956 \\
1955 \\
1954 \\
1953 \\
1952\end{array}$ & $\begin{array}{l}6,645 \\
6,807 \\
6,642 \\
6,438 \\
5,897\end{array}$ & $\begin{array}{l}5,072 \\
5,137 \\
4,867 \\
4,510 \\
4,179\end{array}$ & $\begin{array}{l}\text { 76. } 3 \\
75.5 \\
73.3 \\
70.1 \\
70.9\end{array}$ & $\begin{array}{l}26.0 \\
26.2 \\
25.9 \\
23.9 \\
22.6\end{array}$ & $\begin{array}{l}34.1 \\
32.8 \\
31.0 \\
31.2 \\
32.0\end{array}$ & $\begin{array}{l}\text { 7. } 0 \\
8.0 \\
7.6 \\
6.5 \\
7.1\end{array}$ & $\begin{array}{l}9.2 \\
8.5 \\
8.8 \\
8.5 \\
9.2\end{array}$ \\
\hline $\begin{array}{l}1951 \\
1950 \\
1949\end{array}$ & $\begin{array}{l}5,804 \\
5,342 \\
4,727 \\
5,216\end{array}$ & $\begin{array}{l}4,098 \\
3,759 \\
3,629 \\
4,193\end{array}$ & $\begin{array}{l}\text { 70. } 6 \\
\text { 70. } 4 \\
\text { 76. } 8 \\
\text { 80. } 4\end{array}$ & $\begin{array}{l}23.5 \\
23.5 \\
26.6 \\
28.4\end{array}$ & $\begin{array}{l}\text { 30. } 8 \\
\text { 30. } 8 \\
\text { 31. } 3 \\
\text { 33. } 4\end{array}$ & $\begin{array}{l}\text { 7. } 3 \\
6.8 \\
\text { 8. } 5 \\
\text { 8. } 5\end{array}$ & $\begin{array}{r}9.0 \\
9.3 \\
10.4 \\
10.1\end{array}$ \\
\hline
\end{tabular}

1 Federal and non-Federal physicians in training programs, private practice, and other forms of practice who indicated a primary specialty other than general practice.

2 Internal medicine and its subspecialties, dermatology, and pediatrics.

3 General surgery, anesthesiology, neurological surgery, obstetrics-gynecology, ophthalmology-otolaryngology, orthopedic surgery, plastic surgery, proctology, thoracic surgery, and urology.

4 Administrative medicine, pathology, physical medicine-rehabilitation, preventive medicine and its special fields, and radiology. 
Table 3. Certification by American Specialty Boards by 1962 of physicians graduated from U.S. medical schools in 1948-57

\begin{tabular}{|c|c|c|c|c|c|c|c|}
\hline \multirow{2}{*}{ Year graduated } & \multirow{2}{*}{$\begin{array}{l}\text { Number } \\
\text { active } \\
\text { in U.S. } \\
\text { in } 1962\end{array}$} & \multirow{2}{*}{$\begin{array}{l}\text { Number } \\
\text { certified }\end{array}$} & \multicolumn{5}{|c|}{ Percent of active physicians with designated certification } \\
\hline & & & $\begin{array}{l}\text { Any cer- } \\
\text { tification }\end{array}$ & Medical & Surgical & $\begin{array}{c}\text { Psychiatry, } \\
\text { neurology }\end{array}$ & Other \\
\hline \multirow[t]{3}{*}{$\begin{array}{l}1957 \\
1956 \\
1954 \\
1953 \\
1952\end{array} 1950$} & $\begin{array}{l}6,599 \\
6,645 \\
6,807 \\
6,642 \\
6,438 \\
5,897 \\
5,804 \\
5,342 \\
4,727 \\
5,216\end{array}$ & $\begin{array}{r}9 \\
271 \\
773 \\
1,330 \\
1,844 \\
2,206 \\
2,360 \\
2,175 \\
2,294 \\
2,805\end{array}$ & $\begin{array}{r}0.1 \\
4.1 \\
11.4 \\
20.0 \\
28.6 \\
37.4 \\
40.7 \\
40.7 \\
48.5 \\
53.8\end{array}$ & $\begin{array}{r}0 \\
1.9 \\
4.4 \\
7.3 \\
9.7 \\
11.1 \\
12.6 \\
12.6 \\
16.2 \\
17.8\end{array}$ & $\begin{array}{l}\text { (1) } \\
0.2 \\
3.3 \\
6.2 \\
11.5 \\
16.7 \\
17.9 \\
18.4 \\
20.2 \\
23.5\end{array}$ & $\begin{array}{l}\text { (1) } \\
\\
\text { 1. } 2 \\
\text { 2. } 0 \\
\text { 3. } 1 \\
\text { 3. } 7 \\
\text { 3. } 5 \\
\text { 4. } 9 \\
\text { 5. } 1\end{array}$ & $\begin{array}{l}0.1 \\
2.0 \\
\text { 3. } 5 \\
4.9 \\
\text { 5. } 4 \\
6.5 \\
6.5 \\
6.2 \\
7.2 \\
7.4\end{array}$ \\
\hline & \multirow{2}{*}{$\begin{array}{l}\text { Number } \\
\text { special- } \\
\text { ized } \\
\text { in } 1962\end{array}$} & \multirow{2}{*}{$\begin{array}{l}\text { Number } \\
\text { certified }\end{array}$} & \multicolumn{5}{|c|}{ Percent of specialists of each type with certification } \\
\hline & & & Total & Medical & Surgical & $\begin{array}{c}\text { Psychiatry, } \\
\text { neurology }\end{array}$ & Other \\
\hline $\begin{array}{l}1957 \\
1956 \\
1955 \\
1954 \\
1953 \\
1951 \\
1950 \\
1949\end{array}$ & $\begin{array}{l}5,002 \\
5,072 \\
5,137 \\
4,867 \\
4,510 \\
4,179 \\
4,098 \\
3,759 \\
3,629 \\
4,193\end{array}$ & $\begin{array}{r}9 \\
271 \\
773 \\
1,330 \\
1,844 \\
2,206 \\
2,360 \\
2,175 \\
2,294 \\
2,805\end{array}$ & $\begin{array}{r}0.2 \\
5.3 \\
15.0 \\
27.3 \\
40.9 \\
52.8 \\
57.6 \\
57.9 \\
63.2 \\
66.9\end{array}$ & $\begin{array}{r}0 \\
7.1 \\
16.6 \\
28.2 \\
40.8 \\
49.0 \\
53.8 \\
53.5 \\
60.7 \\
62.7\end{array}$ & $\begin{array}{r}\left.{ }^{1}\right) \\
0.7 \\
10.1 \\
20.0 \\
36.8 \\
52.1 \\
57.9 \\
59.8 \\
64.8 \\
70.4\end{array}$ & $\begin{array}{r}0 \\
.4 \\
2.2 \\
21.4 \\
30.8 \\
44.5 \\
51.1 \\
51.4 \\
58.1 \\
59.9\end{array}$ & $\begin{array}{r}1.2 \\
21.3 \\
41.3 \\
55.6 \\
63.9 \\
70.7 \\
71.8 \\
67.2 \\
69.0 \\
73.0\end{array}$ \\
\hline
\end{tabular}

1 Less than 0.05 percent.

Table 4. Type of practice and specialization in 1962 of physicians graduated from U.S. medical schools in 1949-60

\begin{tabular}{|c|c|c|c|c|c|c|c|}
\hline \multirow{2}{*}{$\begin{array}{l}\text { Year graduated and type } \\
\text { of practice }^{1}\end{array}$} & \multirow{2}{*}{$\begin{array}{l}\text { Number } \\
\text { active } \\
\text { in U.S. } \\
\text { in } 1962\end{array}$} & \multirow{2}{*}{$\begin{array}{l}\text { Number } \\
\text { special- } \\
\text { ized }\end{array}$} & \multicolumn{5}{|c|}{$\begin{array}{c}\text { Percent of active physicians with designated } \\
\text { specialization }\end{array}$} \\
\hline & & & $\begin{array}{c}\text { Any } \\
\text { specialty }\end{array}$ & Medical & Surgical & $\begin{array}{c}\text { Psychiatry, } \\
\text { neurology }\end{array}$ & Other \\
\hline $\begin{array}{l}\text { 1959-60, total } \\
\text { Training programs } \\
\text { Private practice. } \\
\text { Other practice }\end{array}$ & $\begin{array}{r}13,722 \\
8,575 \\
3,536 \\
1,611\end{array}$ & $\begin{array}{r}9,396 \\
8,050 \\
716 \\
630\end{array}$ & $\begin{array}{l}\text { 68. } 5 \\
93.9 \\
20.2 \\
\text { 39. } 1\end{array}$ & $\begin{array}{r}24.9 \\
\text { 34. } 2 \\
8.1 \\
12.0\end{array}$ & $\begin{array}{r}27.8 \\
38.3 \\
7.9 \\
14.9\end{array}$ & $\begin{array}{r}\text { 7. } 5 \\
11.2 \\
1.0 \\
2.4\end{array}$ & $\begin{array}{r}\text { 8. } 3 \\
10.2 \\
3.2 \\
9.8\end{array}$ \\
\hline $\begin{array}{l}\text { 1957-58, total } \\
\text { Training programs } \\
\text { Private practice. } \\
\text { Other practice }\end{array}$ & $\begin{array}{r}13,280 \\
6,767 \\
4,670 \\
1,843\end{array}$ & $\begin{array}{l}9,921 \\
6,613 \\
1,964 \\
1,344\end{array}$ & $\begin{array}{l}\text { 74. } 7 \\
97.7 \\
\text { 42. } 1 \\
\text { 72. } 9\end{array}$ & $\begin{array}{l}24.4 \\
26.2 \\
19.5 \\
30.3\end{array}$ & $\begin{array}{l}\text { 33. } 1 \\
48.9 \\
15.5 \\
19.6\end{array}$ & $\begin{array}{r}\text { 7. } 7 \\
10.1 \\
3.3 \\
10.2\end{array}$ & $\begin{array}{r}9.5 \\
12.5 \\
3.8 \\
12.8\end{array}$ \\
\hline $\begin{array}{l}\text { 1953-56, total } \\
\text { Training programs } \\
\text { Private practice } \\
\text { Other practice }\end{array}$ & $\begin{array}{r}26,532 \\
4,946 \\
16,985 \\
4,601\end{array}$ & $\begin{array}{r}19,586 \\
4,869 \\
10,633 \\
4,084\end{array}$ & $\begin{array}{l}\text { 73. } 8 \\
98.4 \\
62.6 \\
88.8\end{array}$ & $\begin{array}{l}25.5 \\
25.3 \\
23.9 \\
31.6\end{array}$ & $\begin{array}{l}32.3 \\
50.8 \\
28.6 \\
25.9\end{array}$ & $\begin{array}{r}\text { 7. } 3 \\
9.9 \\
5.3 \\
12.0\end{array}$ & $\begin{array}{r}8.7 \\
12.4 \\
4.8 \\
19.3\end{array}$ \\
\hline $\begin{array}{l}\text { 1949-52, total } \\
\text { Training programs } \\
\text { Private practice } \\
\text { Other practice. }\end{array}$ & $\begin{array}{r}21,770 \\
556 \\
17,829 \\
3,385\end{array}$ & $\begin{array}{r}15,665 \\
535 \\
12,182 \\
2,948\end{array}$ & $\begin{array}{l}\text { 72. } 0 \\
96.2 \\
68.3 \\
\text { 87. } 1\end{array}$ & $\begin{array}{l}23.9 \\
11.3 \\
23.4 \\
28.7\end{array}$ & $\begin{array}{l}31.3 \\
39.2 \\
33.3 \\
18.8\end{array}$ & $\begin{array}{r}7.4 \\
22.7 \\
6.0 \\
12.4\end{array}$ & $\begin{array}{r}9.4 \\
23.0 \\
5.6 \\
27.2\end{array}$ \\
\hline
\end{tabular}

${ }_{1}^{1}$ Federal and non-Federal physicians included in each type of practice. Federal physicians who provide direct care to patients outside of hospitals are tabulated as private practice. 


\section{Certification}

Specialty board certification of the 1948-57 graduates is shown in table 3. As mentioned, the young doctor needs several years of residency training to be qualified for certification by one of the 19 American specialty boards. For this reason physicians graduated from U.S. medical schools after 1957 have been omitted from table 3 .

By 1962, 0.1 percent of the physicians graduated in the class of 1957 held certificates from a national board. In the class of 1954 the proportion had reached 20.0 percent; in the class of 1951 , double that rate.

By 14 years out of medical school, more than half of the active physicians were diplomates. Larger numbers were certified in the surgical and the medical fields than in psychiatry-neurology and in other specialties.

By 14 years out of medical school, two-thirds of the specialists were certified, as shown on the lower half of table 3. The combined group of radiologists, pathologists, and other fields showed the largest proportion certified (73 percent), closely followed by the surgical fields (70 percent). The medical fields and psychiatryneurology had slightly lower proportions who were diplomates, about 60 percent each.

\section{Practice and Specialization}

To study specialization in relation to type of practice, several graduating classes have been combined for the presentation in table 4. The combinations show the two classes of 1959 and 1960, the two classes of 1957 and 1958, the four classes between 1953 and 1956, and the four classes between 1949 and 1952. The class of 1961 has been omitted since all the graduates are in the same type of practice (that is, training programs) and data on their specialization appear in table 2. Data for 1948 have also been omitted.

American specialty boards usually require 2 to 3 years of residency or other formal training for the medical specialties. This period is shorter than the 3 to 5 years for the surgical specialties, the 3 to 5 years for psychiatry and neurology, and the 3 to 4 years for pathology, physical medicine-rehabilitation, preventive medicine, and radiology. Thus the proportion of physicians in training who are specializing in the medical fields decreases from 34 percent during the second and third years after graduation to 25 percent during the sixth to ninth years. At the same time the proportion of those in training who are specializing in the surgical fields increases from 38 to 51 percent.

Among physicians in private practice (and this category also may include Federal physicians not associated with a hospital but who provide direct care to patients), the proportion who specialize increases from 20 percent during the second and third years after graduation to 68 percent during the 10 th to 13 th years. Within each of the four specialty groups the proportion shows a steady rise for these same years: from 8 to 23 percent for medical fields, from 8 to 33 percent for surgical fields, from 1 to 6 percent for psychiatry-neurology, and from 3 to 6 percent for other fields.

Among those in hospital service (excluding interns and residents) or in other forms of practice such as teaching, administration, research, or preventive medicine, 39 percent are reported as specialists during the second and third years

\section{Figure 2. Age distribution of physicians, 1962}

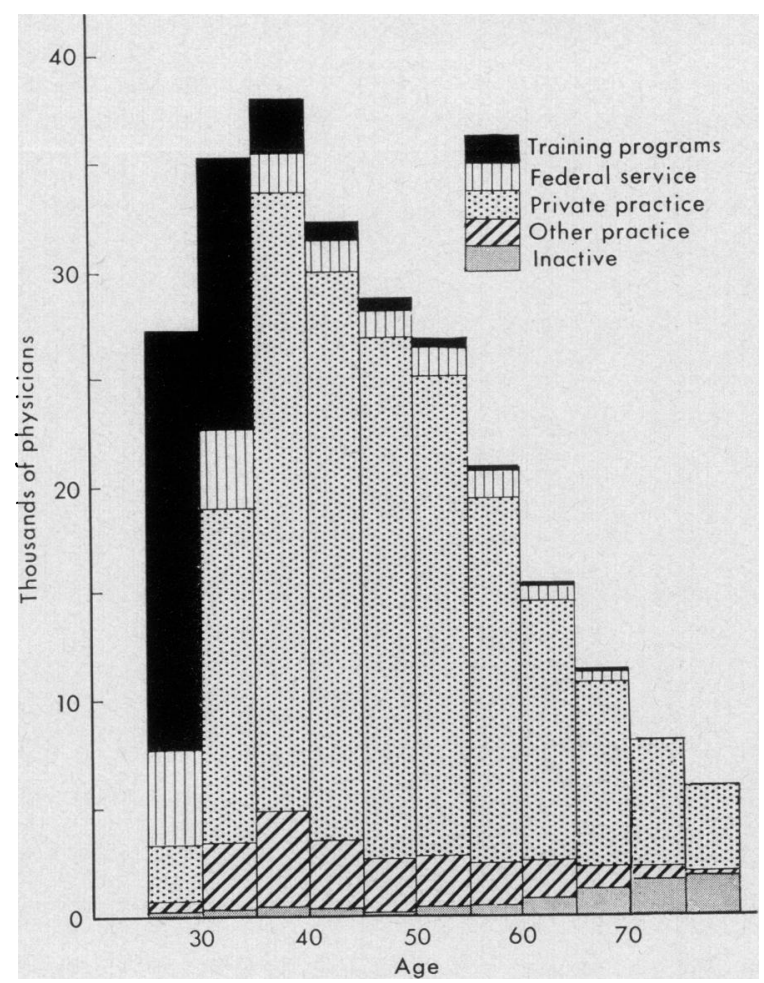


Table 5. Type of practice of physicians in the United States in 1962, by 5-year age groups

\begin{tabular}{|c|c|c|c|c|c|c|}
\hline \multirow{2}{*}{ Age group (years) } & \multirow{2}{*}{ Total } & $\underset{\text { programs }}{\text { Training }}$ & $\begin{array}{l}\text { Federal } \\
\text { service }\end{array}$ & $\begin{array}{c}\text { Private } \\
\text { practice }^{2}\end{array}$ & $\begin{array}{c}\text { Other } \\
\text { practice }{ }^{2}\end{array}$ & Inactive \\
\hline & & \multicolumn{5}{|c|}{ Number of physicians } \\
\hline \multirow{3}{*}{$\begin{array}{l}\quad \text { All ages. } \\
20-29 \\
30-34 \\
35-39 \\
40-44 \\
45099 \\
50-549 \\
60-64\end{array}$} & 257,035 & 35,740 & 16,531 & 170,066 & 22,458 & 12,240 \\
\hline & $\begin{array}{l}27,277 \\
35,360 \\
38,012 \\
32,358 \\
28,875 \\
26,800 \\
20,898 \\
15,555 \\
11,438 \\
20,462\end{array}$ & $\begin{array}{r}19,516 \\
12,405 \\
2,505 \\
798 \\
315 \\
131 \\
46 \\
16 \\
5 \\
3\end{array}$ & $\begin{array}{l}4,642 \\
3,851 \\
1,815 \\
1,371 \\
1,312 \\
1,380 \\
1,097 \\
652 \\
292 \\
119\end{array}$ & $\begin{array}{r}2,466 \\
15,798 \\
28,892 \\
26,474 \\
24,326 \\
22,403 \\
17,177 \\
12,287 \\
8,547 \\
11,696\end{array}$ & $\begin{array}{r}553 \\
3,126 \\
4,454 \\
3,463 \\
2,687 \\
2,569 \\
2,139 \\
1,647 \\
1,047 \\
773\end{array}$ & $\begin{array}{r}100 \\
180 \\
346 \\
252 \\
235 \\
317 \\
439 \\
953 \\
1,547 \\
7,871\end{array}$ \\
\hline & \multicolumn{6}{|c|}{ Percent of physicians } \\
\hline All ages_ & 100.0 & 13.9 & 6.4 & 66.2 & 8.7 & 4. 8 \\
\hline $\begin{array}{l}20-29 \\
30-34 \\
35-39 \\
40-44 \\
45-49 \\
50-54 \\
55-59 \\
60-64 \\
6509\end{array}$ & $\begin{array}{l}100.0 \\
100.0 \\
100.0 \\
100.0 \\
100.0 \\
100.0 \\
100.0 \\
100.0 \\
100.0 \\
100.0\end{array}$ & 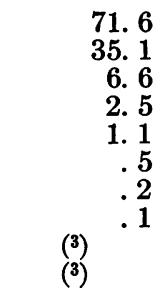 & $\begin{aligned} 17.0 \\
10.9 \\
4.8 \\
4.2 \\
4.5 \\
5.1 \\
5.3 \\
4.2 \\
2.6 \\
.6\end{aligned}$ & $\begin{aligned} 9.0 \\
44.7 \\
76.0 \\
81.8 \\
84.3 \\
83.6 \\
82.2 \\
79.0 \\
74.7 \\
57.1\end{aligned}$ & $\begin{aligned} 2.0 \\
8.8 \\
11.7 \\
10.7 \\
9.3 \\
9.6 \\
10.2 \\
10.6 \\
9.2 \\
3.8\end{aligned}$ & $\begin{array}{r}.4 \\
.5 \\
.9 \\
.8 \\
.8 \\
1.2 \\
2.1 \\
6.1 \\
13.5 \\
38.5\end{array}$ \\
\hline
\end{tabular}

1 Federal and non-Federal physicians.

2 Non-Federal physicians only.

${ }^{3}$ Less than 0.05 percent.

after graduation. The proportion who specialize increases rapidly and is 87 percent during the 10th to 13 th years. Within the specialty groups, the proportion choosing surgery does not increase as markedly as the other three.

\section{Practice and Age}

To obtain information on the career patterns of physicians beyond the first 14 years out of medical school, a tabulation by age of physicians according to type of practice has been prepared (table 5 and fig. 2). The data are based on all graduates of U.S. and foreign medical schools located in this country in 1962.

Among the physicians under age 30, the great majority (71.6 percent) were in training programs. By the next age interval, 30-34 years, the proportion who were interns or residents had dropped to 35.1 percent, with a sharp decline in the succeeding ages.

Physicians in Federal service (excluding in- terns and residents) accounted for the next largest proportion of those in the youngest ages-17.0 percent. At ages $30-34$ years the Federal share was 10.9 percent. From age 35 to retirement the proportion of physicians who chose to be career medical officers remained almost constant, at about 5 percent. The median age for all 16,531 physicians in Federal service was 34.7 years; half were under and half were over that specific age.

As noted previously, upon completion of their internship and residency training and military obligation, increasing numbers of physicians make their start in private practice. For those in ages 35-39 years this proportion was as high as 76.0 percent; by ages $45-49$ and $50-54$ years, about 84 percent. Only after age 70 did the level drop off and even then only to 57 percent. The median age of all 170,066 physicians reported as engaged in private practice was 47.3 years. 
After they finish their postgraduate training and military service, non-Federal physicians also enter other forms of practice, which account for 11.7 percent of the physicians at ages 35-39. The proportion stayed between 11.7 and 9 percent up to age 70 . The median age for physicians in these combined forms of other practice was 44.5 years.

Those inactive remained at less than 1 percent up to age 50 . By age 65 they numbered 13.5 percent; by age 70 and older, 38.5 percent. Included in this category are those who have retired from medical practice because of illness or age, as well as some who are active in fields other than medicine. Obviously many physicians do not retire just because they have reached age 65 or some such arbitrary limit. The data in table 5 indicate that 20,243 physicians are engaged in private practice at ages 65 or older. It may be supposed that as they grow older, they cut back on their practice by seeing fewer patients.

\section{Summary}

The 1962 American Medical Association information on type of practice, specialization, and certification of physicians graduated from U.S. medical schools between 1948 and 1961 has been used to determine how the physician undertakes his career in medicine during the first 14 years after graduation.

All but a few of the young doctors serve their internship in a hospital the first year after graduation. About two-thirds continue in residency training their second year. As they complete their internship and residency training, they either enter Federal service or private practice.

During the second year out of medical school about one-fifth are employed by the Federal Government (exclusive of interns and residents). The proportion in the Federal service stays at about this level through the sixth year, declining to about 5 percent from the ninth year on.

During the second year after graduation about one-ninth of these recent graduates are in private practice. By the seventh year the proportion in private practice has exceeded half; by the ninth year, three-fourths.
Not many of the young physicians start out full time in hospital service, medical school teaching, administrative medicine, research, and preventive medicine. By the fifth year after graduation the proportion in these "other forms of practice" is 5 percent, staying at about 10 to 12 percent from the eighth year on.

That nearly every doctor desires to be a specialist is borne out by the data showing that by the second year after graduation two-thirds of these recent graduates have made a choice of specialty. The proportion gradually increases to about three-fourths. Surgery and related fields are the primary choice. Medical fields claim the next largest numbers of these young doctors. By the 14th year after graduation 33 percent have chosen the surgical fields; 28 percent, the medical fields; 10 percent, pathology, physical medicine, preventive medicine or radiology; 9 percent, psychiatry or neurology. The remaining 20 percent indicate general practice rather than specialization.

By 14 years out of medical school half of the physicians hold certificates from one of the 19 American specialty boards. Two-thirds of the specialists are certified.

A tabulation of all physicians in this country according to type of practice and age shows that, among those under 30 years of age, 72 percent are in training programs, 17 percent in Federal service, 9 percent in private practice. For those in the age group 35-39 years, the proportion in private practice is as high as 76 percent, increasing to 84 percent at ages $50-59$. Other forms of practice account for 12 percent of those in ages 35-39, and the proportion stays between that level and 9 percent up to age 70 . Retirement claims 30 percent of those age 65 and older. Considerable numbers of these physicians at ages 65 and over continue to engage in private practice.

\section{REFERENCES}

(1) Nunemaker, J. C., Thompson, W. V., and Tracy, R.: Graduate medical education in the United States. JAMA 186: 650-718, Nov. 16, 1963, table 20.

(2) Peterson, P. Q., and Pennell, M. Y.: Health manpower source book 14 . Medical specialists. PHS Publication No. 263, sec. 14. U.S. Government Printing Office, Washington, D.C., 1962. 